\title{
The Path of Producer Services Promoting China's Manufacturing Structure Upgrade: An Empirical Study Based on Structural Equation Model
}

\author{
Wang Ying \\ Professor in College of Economics and Management, \\ Nanjing University of Aeronautics and Astronautics, Nanjing, China \\ Phone: 86-25-84893274; Fax: 86-25-84892752; Email: yingwang@nuaa.edu.cn \\ Nguyen Thi Dieu Linh \\ College of Economics and Management, \\ Nanjing University of Aeronautics and Astronautics, Nanjing, China \\ Email:dieulinh_cn@yahoo.com \\ Shi Pengcheng \\ College of Economics and Management, \\ Nanjing University of Aeronautics and Astronautics, Nanjing, China \\ Email: spengc@yahoo.cn
}

Doi:10.5901/ajis.2013.v2n9p135

\section{Abstract}

Producer services play an import role in accelerating the development of manufacturing industry; however, the path that producer services promoting China's manufacturing structure upgrade has not been adequately studied. According to provinces' panel data in China from 2000 to 2010, structural equation model is built up to empirically analyze the effect and path that producer services affect its manufacturing structure upgrade. It is showed that: producer services significantly promote manufacturing structure upgrade; producer services promote manufacturing structure upgrade through direct and indirect effect, where indirect effect is greater than direct effect; the indirect effect reached by stimulating demand is much greater than by improving technology.

Keyword: Producer Services; Manufacturing Structure Upgrade; Structural Equation Model

\section{Background and literature review}

In the era of services economy, producer services, as an important part of services industry, has developed rapidly and become a pillar industry in many European and American countries and even some developing countries. According to 2012 International Statistical Yearbook, services industries in developed countries and regions contributed a 70\% increase in GDP, while producer services sector accounted for the proportion of more than $50 \%$.

China is now in a critical period of new economic development mode in which its purpose is to optimize industrial structure and achieve economic-social-environment development coordination. Industrial structure optimization reflects not only the relationship between three strata industries, but also the development of intra-industry. Since producer services represents service sector's development level, and it also can promote manufacturing industry development, therefore it obviously has become one of most important industry which needs to be emphasized in. Then researches on producer services are flourishing, with the relationship between producer services and manufacturing industry becoming one of most prominent research focus.

Producer services in fact were born out of manufacturing industry. Following with the strengthening and deepening of the social division and competitiveness level, producer services has been separated from manufacturing industry to become an independent department. Also, going after the improvement of economic development, the share of producer services is raising up. As soon as producer services reach a certain development level, with powerful support functions to nurturing manufacturing industry, it simultaneously decreases investment capital and increases investment quality to be 
conducive to the specialization and refinement of manufacturing industry and then becomes traction and propulsion of manufacturing industry growth (Andersson, 2004; Liu, 2006).

Many scholars have conducted empirical researches on the mutual relation between producer services and manufacturing industry to show the promotion role of producer services for manufacturing growth. For instance, Selya (1994) pointed out that, producer services are able to upgrade manufacturing industry's competitiveness, achieve space reconstruction of metropolitan manufacturing sector as it is one of the driving forces of the economic development; Research of Jiang Jing, Liu Zhibiao and Yu (2007) recognized that the expansion of producer services promote manufacturing industry's overall efficiency improvement; Gao and Li (2011) discovered that the development of producer services has remarkable effect in promoting manufacturing industry growth, and vice versa. Also, there exists an interactive development within producer services' internal departments and manufacturing. Zhao and Cheng (2012) found that the higher producer services' economic level was, the stronger role in promoting manufacturing development would be. Pang (2012) considered that China's producer services and manufacturing industry are now at growing stage in which the interactive development between these two sectors is asymmetrically mutualistic; the influence of producer services on manufacturing industry is more than that of manufacturing industry on producer services.

In further research, scholars not only emphasized on the role of producer services towards manufacturing industry growth, but have begun to show their consideration on the role and path of producer services towards upgrading manufacturing structure. Lu (2008) claimed that the development of producer services towards whole economy mainly reflects in two aspects: to promote the optimizing and upgrading industrial structure and to enhance industrial competitiveness; services industry lagging behind manufacturing industry and insufficient producer services development are the major reasons restricting the upgrading of China's manufacturing industry structure. Based on Beijing's inputoutput data and by using input-output method to research on the relation between producer services' development and industrial structure adjustment, Xia (2008) concluded that producer services' development plays a crucial role towards Beijing's industrial structure adjustment. Han (2010) took Ningbo as example in his empirical research, recognizing that producer services development holds a very important help for Ningbo's manufacturing industry's upgrading.

Although many scholars have made numbers of available empirical researches on the relationship between producer services and manufacturing upgrade, there are incompleteness as follows: (1) producer services are separated out from manufacturing industry so it naturally has relevant relation with manufacturing industry growth; therefore available researches mainly focused on the relation between producer services and manufacturing industry growth but neglected the influence of producer services on manufacturing structure upgrade; (2) such researches rarely used empirical method to testify the path of producer services influencing manufacturing structure upgrade. They usually used theoretical speculation method to explain the internal mechanisms, lacking of strong data demonstration. Thus, structural equation model will be built up in this research to analyze how producer services influences manufacturing structure upgrade, which complements the current available researches and therefore achieves relevant revelations of promoting China's manufacturing structure upgrade by developing producer services.

\section{Building Structural Equation Model}

Structural equation model (SEM) is a multivariate statistical analysis technique which combines multiple regression and factor analysis organically so as to evaluate automatically a series of syntrophic causal relationship. SEM has similar usages as multiple regression, but it holds stronger function, which is suitable for modeling in complicated condition including latent variables, independent variables relevance, variables, multiple dependent variables, and so on. To be a powerful replacement of multiple regression, path analysis, time series analysis and covariance analysis as well as other methods, SEM has contributed large sort of applications in economics, sociology and social sciences field (Hou, Wen \& Chen, 2003; Wu, 2012).

\subsection{Research assumptions and conceptual model}

Scholars' researches results have shown that, on one hand, being the intermediate input of manufacturing industry, producer services are able to improve effectively manufacturing industry's productivity, and then promote its structure upgrade; on the other hand, producer services can promote manufacturing structure upgrade through its function on demand and technological progress. Therefore, the following five assumptions are come up with served as the basis of Structural equation modeling.

H1: Producer services have significantly positive direct impact on manufacturing structure upgrade. 
Producer service industry, separated from specialized division of manufacturing industry, is a particular department which is set apart from the internal manufacturing industry to provide services for producing. It is able to raise productivity, reduce producing costs, improve the added value of products, and then increase the value-added technological level in the whole manufacturing industry, which is helpful for adjusting the manufacturing structure.

$\mathrm{H} 2$ : Producer services have significantly positive direct impact on demand.

Producer service industry run throughout upstream, midstream and downstream of the production progress; it holds a high-teach content, internationalization and other particular features which help producer services strong enough to lift up domestic commodities' value-added, to strengthen international competitiveness, and thus raise export and domestic market demand.

H3: Producer services have significantly positive direct impact on technological progress.

Producer services are actually with a very close relation with knowledge and technology; its producing process needs to invest much knowledge and technology, highly specialized knowledge capital and technology capital are then accumulated, thus condense in produced goods and services to promote technological progress.

H4: Demand has significantly positive direct impact on manufacturing structure upgrade.

The final objective of production is to satisfy people's demands. When demand changes, it will affect inevitably on manufacturing structure. Changes in demand will lead to contradictions and maladjustment between the original producing structure and demand structure. New manufacturing department is now required to replace for the old one. Manufacturing industry structure is then to be upgraded.

H5: Technological progress has significantly positive direct impact on manufacturing structure upgrade.

Technological progress has provided new tool and producing method by using scientific management to improve productivity efficiency so that producing costs are reduced. Diversity of technological innovation capability will accelerate social and economic resources' transferring from lower productivity department to higher one, thus promote manufacturing structure upgrade.

In view of the above assumptions, a conceptual model (Figure 1) can be obtained showing the relationship between producer services, demand, technological progress and manufacturing structure upgrade, which is served as the basis of the empirical model, where the straight lines represent the corresponding research assumptions, while the plusminus signs in the brackets indicate the functioning direction.

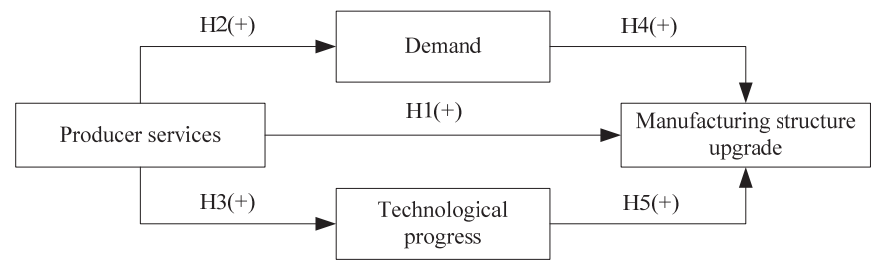

Figure 1. Conceptual model of producer services promoting manufacturing structure upgrade

\subsection{The empirical model}

Constructing structural equation model of producer services, influence factors and manufacturing structure upgrade results in the path coefficients, revealing the direct and indirect impact of producer services on manufacturing structure upgrade. On the basic of check analysis on variables, four latent variables and fifteen observation variables are adopted in the SEM as follows.

Producer services index (S) is selected primarily based on the production function, where GDP growth rate of producer services (S1) represents for the dynamical development state of producer services; employment in producer services (S2) indicates labor factor input; fixed assets investment (S3) and financial investment (S4) reflect capital factor input.

Using manufacturing sub-industry output value proportion to measure manufacturing structure upgrade $(\mathrm{M})$, showing in details by the proportion of resource-intensive industry output value to manufacturing industry output (M1), labor-intensive industry output value to manufacturing industry output (M2), capital-intensive industry output value to manufacturing industry output (M3), capital and technology-intensive industry output value to manufacturing industry output (M4). The resource-intensive industry, labor-intensive industry, capital-intensive industry, and capital and 
technology-intensive industry are calculated according to OECD's manufacturing industry technology classification method.

Demand (D) includes not only demand growth but also change in demand structure. The value-added appreciation brought by services development will raise high-level needs. For that reason, services development (D1) itself is an index for measuring demand, which is specifically denoted by foreign demand and domestic demand. Engel coefficient (D2) and export dependence degree (D3) are used to represent for domestic and foreign demand respectively.

Indicators of technological progress $(T)$ are also selected from production function, using college faculty growth rate (T1) to indicate labor factor investment; using effective patents growth rate (T2) and technological market share of GDP (T3) to show the dynamical development level of technological market; using scientific and education financial investment growth rate (T4) to denote capital factor investment.

Names and meanings of variables are provided in Table 1.

Table 1. Names and meanings of variables

\begin{tabular}{|c|c|c|}
\hline Latent variable & $\begin{array}{l}\text { Observation } \\
\text { variables }\end{array}$ & Meanings \\
\hline \multirow{5}{*}{$\begin{array}{l}\text { Producer services } \\
\text { (Exogenous latent } \\
\text { variable, S) }\end{array}$} & S1 & Producer services GDP growth rate (\%) \\
\hline & S2 & Producer services employment (10,000 persons) \\
\hline & S3 & Producer services fixed assets investment growth rate (\%) \\
\hline & S4 & Producer services financial investment growth rate (\%) \\
\hline & M1 & $\begin{array}{l}\text { Ratio of resource-intensive industry output value to manufacturing } \\
\text { industry output (\%) }\end{array}$ \\
\hline \multirow{3}{*}{$\begin{array}{l}\text { Manufacturing industry } \\
\text { upgrade } \\
\text { (Endogenous latent } \\
\text { variable, M) }\end{array}$} & M2 & $\begin{array}{l}\text { Ratio of labor-intensive industry output value to manufacturing industry } \\
\text { output (\%) }\end{array}$ \\
\hline & M3 & $\begin{array}{l}\text { Ratio of capital-intensive industry output value to manufacturing } \\
\text { industry output (\%) }\end{array}$ \\
\hline & M4 & $\begin{array}{l}\text { Ratio of capital and technology-intensive -intensive industry output } \\
\text { value to manufacturing industry output (\%) }\end{array}$ \\
\hline \multirow{3}{*}{$\begin{array}{l}\text { Demand } \\
\text { (Endogenous latent } \\
\text { variable, D) }\end{array}$} & D1 & Tertiary industry share of GDP (\%) \\
\hline & $\mathrm{D} 2$ & Engel coefficient (\%) \\
\hline & D3 & Ratio of export to GDP (\%) \\
\hline \multirow{4}{*}{$\begin{array}{l}\text { Technological progress } \\
\text { (Endogenous latent } \\
\text { variables, } \mathrm{T} \text { ) }\end{array}$} & $\mathrm{T} 1$ & College faculty growth rate (\%) \\
\hline & T2 & Effective patents growth rate (\%) \\
\hline & T3 & Technological market share of GDP (\%) \\
\hline & $\mathrm{T} 4$ & Scientific and education financial investment growth rate (\%) \\
\hline
\end{tabular}

Note: producer services include Transport, Storage and Post, Information Transmission, Computer Services and Software, Wholesale and Retail Trades, Financial Intermediation, Leasing and Business Services, Scientific Research, Technical Services and Geologic Prospecting.

According to mentioned assumptions and variables above, let $S$ represent for endogenous variables producer services, $D, T$ and $M$ represent for the endogenous variable demand, technological progress and manufacturing structure upgrade respectively, then the measurement models are constructed as below:

$$
\begin{aligned}
& S_{1}=\lambda_{1} S+\varepsilon_{1} ; \quad S_{2}=\lambda_{2} S+\varepsilon_{2} ; \quad S_{3}=\lambda_{3} S+\varepsilon_{3} ; \quad S_{4}=\lambda_{4} S+\varepsilon_{4} \\
& D_{1}=\lambda_{5} D+\varepsilon_{5} ; \quad G_{2}=\lambda_{6} D+\varepsilon_{6} ; \quad G_{3}=\lambda_{7} D+\varepsilon_{7} \\
& T_{1}=\lambda_{8} T+\varepsilon_{9} ; \quad T_{2}=\lambda_{10} T+\varepsilon_{10} ; \quad T_{3}=\lambda_{11} T+\varepsilon_{11} ; \quad T_{4}=\lambda_{12} T+\varepsilon_{12} \\
& M_{1}=\lambda_{14} M+\varepsilon_{14} ; \quad M_{2}=\lambda_{15} M+\varepsilon_{15} ; \quad M_{3}=\lambda_{16} M+\varepsilon_{1 \dot{ }} \quad M_{4}=\lambda_{17} \eta_{3}+\varepsilon_{17}
\end{aligned}
$$

While $S$ represents for a vector of exogenous observation variables, $D, T$ and $M$ represent for vectors of endogenous observation variables, respectively. The relationship between latent variables is shown by the following structural models. 


$$
\begin{aligned}
& D=H_{2} S+\varepsilon_{8} \\
& T=H_{3} S+\varepsilon_{13} \\
& M=H_{1} S+H_{4} D+H_{5} T+\varepsilon_{18}=H_{1} S+H_{4}\left(H_{2} S+\varepsilon_{8}\right)+H_{5}\left(H_{3} S+\varepsilon_{13}\right)+\varepsilon_{18}
\end{aligned}
$$

\section{Empirical analyses}

\subsection{Variables' descriptive statistics and validity test}

In structural equation model, the selection of sample data directly affects to the validity of empirical research. Panel data of 31 provinces and cities in China from 2000 to 2010 was firstly chosen to conduct the empirical research, however, there is evident difference between manufacturing industry development in these places, therefore, it was decided to confer $50 \%$ of weight for each province and city in producer services and manufacturing output, then excluded Tibet and Qinghai because of their serious missing data and low development level of the producer services. At last, 16 provinces and cities were chosen for this empirical research, including Beijing, Tianjin, Hebei, Inner Mongolia, Liaoning, Shanghai, Jiangsu, Zhejiang, Anhui, Fujian, Shandong, Henan, Hubei, Hunan, Guangdong and Sichuan. Sample size is 176. All the Data are taken from "China Statistical Yearbook", "China Industrial Economy Statistical Yearbook" and Statistical

\begin{tabular}{|c|c|c|c|c|c|}
\hline Variables & $\mathrm{N}$ statistics & Minimum statistics & Maximum statistics & Mean statistics & Standard deviation statistics \\
\hline S1 & 176 & -27.37 & 60.59 & 13.17 & 12.19 \\
\hline S2 & 176 & -16.31 & 34.39 & 0.98 & 6.96 \\
\hline S3 & 176 & -39.80 & 93.43 & 17.84 & 22.71 \\
\hline S4 & 176 & -85.66 & 86.64 & 17.83 & 25.96 \\
\hline M1 & 176 & 4.98 & 4.29 & 1.65 & 9.37 \\
\hline M2 & 176 & 2.07 & 2.62 & 1.01 & 5.84 \\
\hline M3 & 176 & 1.16 & 3.71 & 2.52 & 5.67 \\
\hline M4 & 176 & 1.44 & 7.82 & 4.81 & 1.49 \\
\hline $\mathrm{D} 1$ & 176 & 28.62 & 75.53 & 40.23 & 8.54 \\
\hline D2 & 176 & 30.09 & 45.71 & 36.93 & 3.38 \\
\hline D3 & 176 & 1.62 & 98.86 & 26.70 & 25.07 \\
\hline $\mathrm{T} 1$ & 176 & -6.08 & 26.41 & 7.36 & 5.35 \\
\hline T2 & 176 & -102.90 & 136.27 & 27.53 & 44.33 \\
\hline T3 & 176 & 0.08 & 2.93 & 0.66 & 0.63 \\
\hline T4 & 176 & 4.09 & 25.21 & 17.33 & 3.32 \\
\hline
\end{tabular}
Yearbook of provinces and cities. Initial data descriptive statistics of each index is shown in Table 2.

Table 2. Descriptive statistics results

$\mathrm{KMO}$ and Barlett Test of Sphericity are done then, showing $\mathrm{KMO}=0.70>0.50$, Sig $=0.01<0.05$, indicating better validity of the model data.

\subsection{Parameter estimation and test}

With Amos7.0, using the maximum likelihood method to estimate the parameter, the path coefficients can be figured our (Figure 2). Since the inspection result shows that coefficient and variance are all passing the significance testing, in which chi-square degrees of freedom is $4.22(<5.00)$, absolute fit measure is $0.82(>0.80)$, fit measure is $0.92(>0.90)$ and adjusted fit measure is $0.84(>0.80)$, therefore, this estimation result is acceptable. 


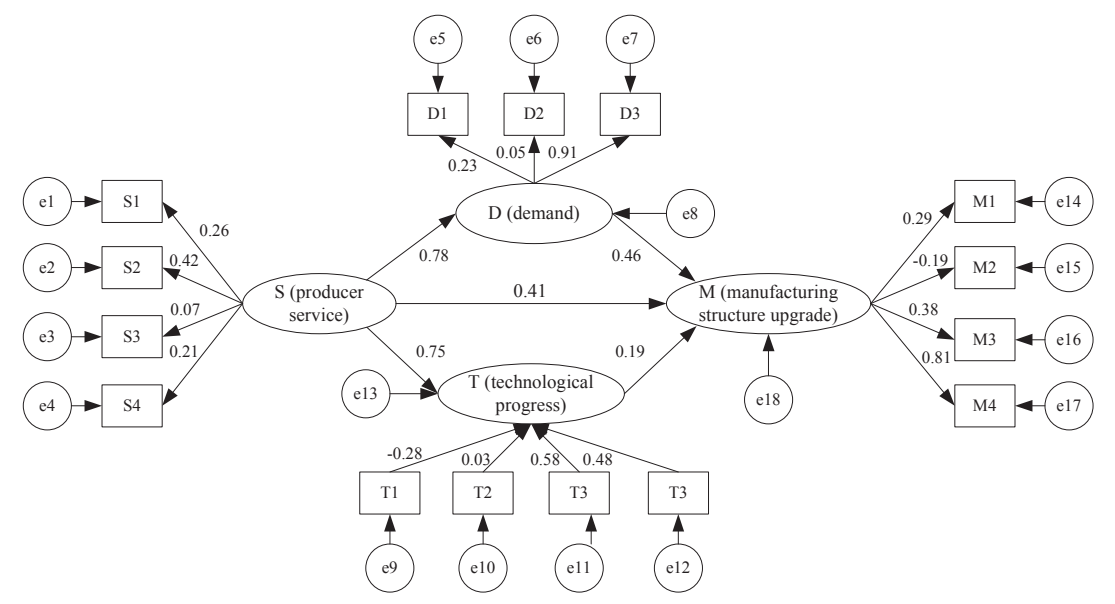

Figure 2. Standardized coefficient parameter estimation results of SEM

\subsection{Result analysis}

Compared with the research assumptions, five conclusions can be achieved.

Firstly, significance level of $\mathrm{H} 1$ is smaller than 0.001 , satisfying assumption 1 , which means producer services have direct impact on manufacturing structure upgrade. From the empirical results, producer services affecting manufacturing structure upgrade holds two effects: direct and indirect effect, where direct effect coefficient is 0.41 , and indirect effect coefficient is $0.50\left(0.78^{\star} 0.46+0.75^{\star} 0.19\right)$. Total effect coefficient of producer services on manufacturing structure upgrade is $0.91(0.41+0.50)$.

Secondly, significance level of $\mathrm{H} 2$ is smaller than 0.001 , satisfying assumption 2, which means producer services have direct impact on demand. The direct effect coefficient of producer services on demand is 0.78 , stating that producer services development can influence demand more considerably.

Thirdly, significance level of $\mathrm{H} 3$ is 0.005 , satisfying assumption 3 , which means producer services have direct impact on technological progress. The direct effect coefficient of producer services on technological progress is 0.75 , explaining that producer services have powerful promotion on technological progress.

Fourthly, significance level of $\mathrm{H} 4$ is 0.013 , satisfying assumption $\mathrm{H} 4$, which means demand has direct impact on manufacturing structure upgrade. The direct effect coefficient of demand on manufacturing structure upgrade is 0.46 , reflecting that demand holds a push for manufacturing structure upgrade.

Fifthly, significance level of H5 is 0.013 , satisfying assumption H5, which means that direct impact of technological progress on manufacturing structure upgrade. The direct effect coefficient of technological progress on manufacturing structure upgrade is 0.19 , relatively lower compared with the path coefficients of demand and producer services on manufacturing structure upgrade.

Comprehensively, producer services have significant impact on manufacturing structure upgrade by direct and indirect paths. The direct effect coefficient is 0.41 , the indirect effect coefficient through demand is $0.36\left(0.78^{\star} 0.46\right)$, and through technological progress is $0.14\left(0.75^{\star} 0.19\right)$.

\section{Conclusions}

Structural equation model is constructed in this paper to do the empirical analysis based on panel data of 16 provinces and cities in China during 2000 and 2010, with the result showing that, producer services not only have straight promoting effect on manufacturing structure upgrade, also have indirect promoting effect on manufacturing structure upgrade by pushing demand and technological progress. The indirect positive effect through demand is much more than through technological progress. This is really helpful for a manufacturing power with services development lagging behind like China, especially when domestic and foreign economic situation has being undergone a huge change currently.

Two main revelations can be obtained from empirical results above: firstly, to provide more support for producer services, perfect policies and regulations, construct a complete and healthy market, so as to promote producer services 
development; secondly, to vigorously develop technological producer services and complete demand structure, promote technological progress and demand development, so as to optimize the path of producer services promoting manufacturing structure upgrade. It not only can effectively compensate for the assault of China's manufacturing industry development causing by the disappearance of "resource dividend" and "demographic dividend", but also can form a benign interactive development situation for producer services and manufacturing structure upgrade.

\section{Ackowledgement}

This paper was supported by NUAA Research Funding under grant NR2011001 and universities' philosophy and social science key project of Jiangsu Education Committee under grant 2010ZDIXM029.

\section{Reference}

Andersson M. (2004). Co-location of manufacturing \& producer services: a simultaneous equation approach. Working Paper Series in Economics and Institutions of Innovation from Royal Institute of Technology.

Gao Juemin \& Li Xiaohui. (2011). Theoretical and Empirical Study on the Interactive Mechanism between Producer Services and Manufacturing. China Industrial Economics, 6, 151-160.

Han Minghua. (2010). Research on producer services promoting industrial structure upgrade-using Ningbo as an example. Reform of Economic System, 4, 51-55.

Hou Jietai, Wen Zhonglin \& Cheng Zijuan. (2003). Structural equation model and its applications. Beijing: Educational Science Publishing House.

Jiang Jing \& Liu Zhibiao. (2007). Produce services development and manufacturing efficiency improvement. The Journal of World Economy, 8, 52-62.

Liu Zhibiao. (2006). Developing modern producer service and adjusting and optimizing structure of manufacturing. Journal of Nanjing University, 5, 36-44.

Lu Hongyan. (2008). Striving to develop producer services and promoting China's industrial structure upgrade. Forward Position in Economics, 4, 68-73.

Pang Bohui. (2010). Research about symbiotic evolutionary model of producer services and manufacturing industry in China. Chinese Journal of Management Science, 20(2), 176-183.

Selya R M. (1994). Taiwan as a service economy. Geoforum, 25(3), 305-322.

Wu Minglong. (2010). Structural equation model. Chongqing: Chongqing University Press.

Xia Qingfang. (2008). Empirical research on relationship between producer services and metropolitan industrial structure adjustment. Statistical Research, 12, 101-102.

Zhao Fang \& Cheng Dan. (2012). Industry relevancy between producer services and manufacturing in East Asia. World Economy Study, 7, 73-79. 